\title{
Food Plants Eaten by Amazonian Manatees (Trichechus inunguis, Mammalia : Sirenia)
}

\author{
Ioni G. Colares ${ }^{1^{*}}$ and Elton P. Colares ${ }^{2}$ \\ ${ }^{1}$ Depto. de Ciências Morfo-Biológicas - Fundação Universidade Federal do Rio Grande (FURG), Av. Italia km 8; \\ ${ }^{2}$ Depto. de Ciências Fisiológicas, FURG - Rua Eng. Alfredo Huch, 475, 96201-900 - Rio Grande-RS, Brazil
}

\begin{abstract}
To determine the feeding habits of the Amazonian manatee Trichechus inunguis in some Central Amazonian rivers and lakes, we compared plant epidermis found in the stomach contents and/or faeces of animals with a reference collection of plants present in the studied areas. Twenty five samples from digestive tracts of animals found dead and 25 faeces samples found floating were analyzed. From these samples, 24 aquatic macrophytes were identified. The Gramineae family was identified in $96 \%$ of the samples, Paspalum repens and Echinochloa polystachya being the most abundant in the samples. The second most frequent family was the Pontederiaceae primarily Eichhornia crassipes. During the high water period, the animals showed a more selective diet (eight identified species). In the low water period, when food was more scarce, the animals showed a larger diversity of species in their diet (21 species of plants). Differences in the diet among the two studied areas reflected the physiographics characteristics of the region. Amazonian manatees fed mostly on emergent plants.
\end{abstract}

Key words : Amazonian manatee, trichechus, food, plants eaten, Amazon

\section{INTRODUCTION}

The Amazonian manatee (Trichechus inunguis) is the only exclusively fresh water sirenian and it is endemic to the Amazon region. It ranges from Marajó Island (Brazil) to the sources of the Amazon basin rivers in Columbia, Peru and Ecuador (Timm et al., 1986). It is present in all the major draining system tributaries of the Amazon river, where its distribution is apparently restricted to two locations: calm waters and lakes with aquatic vegetation (Best, 1984; Rosas et al.,1991; Rosas, 1994). Amazonian manatees are herbivorous, non-ruminant, and feed on a large variety of aquatic and semi-aquatic plants (Timm et al., 1986). However, aquatic grasses are probably their preferred food (Montgomery et al. 1981; Best, 1984; Gonçalves-Colares \& Colares, 1992). Previous studies on the food habits of other sirenian species, Trichechus manatus, $T$. senegalensis and Dugong dugon, were carried out, both by direct animal observation (Hartman, 1979; Bengtson, 1981; Packard, 1981; Anderson, 1998), by analyzing the digestive tract contents (Marsh et al., 1982; Ledder, 1986) and using the stable carbon isotope $\delta^{13} \mathrm{C}$ in captive animals (Ames et al., 1996).

Direct observation of a manatee in the Amazon is nearly impossible due to the turbid, dark water, which limits the visibility to no more than $60 \mathrm{~cm}$. In clear water rivers, such as the Tapajós (Pará), for example, sightings of manatees are rare (Husar, 1977). Therefore, studies on the feeding habits of

\footnotetext{
* Author for correspondence
} 
Amazonian manatees are only possible by analyses of the digestive tract contents of dead animals or of faeces collected in the wild, as well as partially consumed foods (parts of plants left by the animal) or through observation of captive animals (Gonçalves-Colares \& Colares, 1992). Domning (1981) quoted observations made by local fisherman in the regions of Pará, Maranhão, Amazonas and Amapá (Brazil), who confirmed having seen animals feeding on different species of submerged, floating, and emergent plants. The availability of aquatic and semi-aquatic plants on which the manatee feeds (Best, 1984) varies greatly depending on the levels of the rivers between the low and high water periods of the Amazon basin (Junk, 1970; Colares \& Colares, 1987), and is believed that seasonal variation in their diet is due to variation in the availability of these plants (Best, 1981).

The main objective of this study was to determine the feeding habits of the Amazonian manatees ( $T$. inunguis) in some rivers and lakes of the central Amazon.

\section{MATERIALS AND METHODS}

Samples of digestive tract contents of 25 animals found dead and 25 faeces samples found floating were collected from two study areas. Area 1 included Amanã Lake, of $145.3 \mathrm{~km}^{2}\left(2^{\circ} 46^{\prime} \mathrm{S}\right.$ and $64^{0} 39^{\prime} \mathrm{W}$ ), $67 \mathrm{~km}$ north of the city of Tefé (state of Amazonas - AM). Area 2 included the lakes and proximities of Marchantaria Island, of 320 $\mathrm{km}^{2},\left(3^{0} 15^{\prime} \mathrm{S}\right.$ and $\left.60^{\circ} 00^{\prime} \mathrm{W}\right)$, in the Solimões River (AM), as well as Rei Lake, of $100 \mathrm{~km}^{2}$, located in the Careiro Island $\left(3^{0} 05^{\prime} \mathrm{S}\right.$ and $59^{\circ} 35^{\prime}$ $\mathrm{W})$, in the Amazonas River, close to the City of Manaus (AM). Amongst the total of 50 samples analyzed, $35(70 \%)$ came from area 1 and 15 (30\%) from area 2. Of this total, 40 samples $(80 \%)$ were collected in the low water period and 10 samples (20\%) in the high water period.

The digestive tract of each animal was removed and samples were collected from the stomach, the small and large intestines and the caecum. They were preserved in FAA (85\% ethyl alcohol, $10 \%$ formalin at 10\%, 5\% glacial acetic acid). Faeces found floating were also collected and stored in FAA.

Each sample was homogenized and a sub-sample removed. From the sub-sample, five microscope slides were prepared and analyzed, according to the method of Heinsohn \& Birch (1972). Plant species were identified by means of comparison with epidermal layers of previously identified plants which were mounted as a reference collection, following Storr (1961). Identifications were based on size and shape of the epidermal cells, presence and distribution of silica deposits, distribution and types of stomata, and distribution, types and sizes of trichomes and veins. Totally transparent epidermal layers were identified immediately. Those which were not transparent, which still had remains of mesophyll, were first cleaned with a fine brush or immersed in a mixture of $10 \%$ nitric acid $\left(\mathrm{HNO}_{3}\right)$ and $10 \%$ chromic acid $\left(\mathrm{HCrO}_{3}\right)$ (cold acid digestion), for an average of two minutes, depending on the quantity of mesophyll present. The presence of algae or nonvegetative material was also noted.

Data were grouped taking into consideration possible variations between the times of year (low water: September to February, and high water: March to August), and different regions (areas 1 and 2).

\section{RESULTS AND DISCUSSION}

The number of plant species found in a sample varied from one to seven, with a predominance of two or three plant species per animal $(30.6 \%$ and $34.7 \%$ respectively). During high water, a maximum of three species per sample was observed, while during the low water this number reached to seven distinct species. During high water, all species of aquatic plants were more abundant, suggesting higher food availability (Colares \& Colares, 1987). Faeces during low water when food availability was lower, suggested that Amazon manatee had not a selective diet, eating all available species. With more abundant food sources, the number of eaten species decreased, indicating a more selective diet.

In dugongs (D. dugon) and West Indian manatees (T. manatus), several plant species were also found, mixed together in their digestive tracts (Heinsohn \& Birch, 1972; Ledder, 1986). According to Reynolds (1977) and Hartman (1979), West Indian manatees apparently did not select their feeding grounds - at times they remained in one place until food species were totally destroyed, or they passed casually from one area to another. This could also happen with the Amazonian manatee, explaining the variation in 
the number of plants encountered in the digestive tracts and faeces analyzed. Samples made up of different plant species could represent a nutritional complement or feeding in wide-spread feeding grounds made up of different plant species. The sample which only contained one plant species could represent a specific preference for that species or feeding in one dense, monospecific feeding ground. T. inunguis kept captive at INPA (National Institute of Amazonian Research, Brazil) showed a specific preference for Paspalum repens, and fed casually on other species when the preferred one was totally consumed (GonçalvesColares \& Colares, 1992).

Table 1 shows the accumulated number of plants encountered in samples. Twenty two species were identified, of which the animals fed more frequently on emergent plants $(65.1 \%)$ than floating $(31.3 \%)$ or submerged $(3.6 \%)$. This high consumption of emergent plants may be related to feeding adaptation or availability. The surroundings in which this species lives, where, according to Sioli (1968), most of the aquatic plants are floating or emergent, favour this situation. Domning (1978a) suggested that different degrees of deflection in sirenian skulls could be adaptations to feed at different levels in the water column. According to Domning (1978 a), the degrees of deflection in T. manatus and $T$. inunguis were similar. These animals were to feed efficiently anywhere in the water column, which could provide a greater variety of food. However, muscular and articulation peculiarities in the neck of $T$. inunguis provided support for the hypothesis that it was more specialized than the West Indian manatee to feed near the water surface (Domning, 1978b). Of the plants identified, the Gramineae family was the most common, being found in $96 \%$ of the samples analyzed. The more frequent species was Paspalum repens (17.5\%), followed by Echinochloa polystachya (13.8\%).

Table 1 - Percentage of plants identified in samples collected in the digestive tract and faeces from Amazonian manatee.

\begin{tabular}{llllll}
\hline Emergent & $\%$ & Floating & $\%$ & Submerged & $\%$ \\
& & & & & \\
\hline Paspalum repens & 17.5 & Eichhornia crassipes & 11.2 & Utricularia foliosa & 1.8 \\
Echinochloa polystachya & 13.8 & Salvinia auriculata & 8.3 & Cabomba sp. & 1.8 \\
Luziola spruceana & 7.4 & Pistia stratiotes & 6.4 & & \\
Phaseolus pilosus & 6.4 & Ludwigia helmintorriza & 2.7 & \\
Paspalum fasciculatum & 5.6 & Ipomoea aquatica & 1.8 & \\
Panicum chloroticum & 2.7 & Neptunia oleracea & 0.9 & \\
Hymenachne amplexicaulis & 2.7 & & & \\
Panicum chlorantum & 1.8 & & & \\
Panicum laxum & 1.8 & & & \\
Panicum sp. & 1.8 & & & & \\
Oryza latifolia & 0.9 & & & & \\
Oryza perennis & 0.9 & & 31.3 & \\
Oryza grandiglumis & 0.9 & & & \\
Polygonum spectabile & 0.9 & & & & \\
& Total & 65.1 & & &
\end{tabular}

Figure 1 shows that plant consumption varied according to time of year (low or high water). During the low water period, a larger number of vegetable species was consumed (21), while during high water only eight species were identified, of which seven were the same as those identified during low water.
Samples of two manatees collected during the low water period consisted of only Paspalum repens, while Echinochloa polystachya was found as the only food item during high water. This not only suggested a food preference of the Amazonian manatee for these species, but also reflected their abundance in the habitat of these animals. Paspalum repens and Echinochloa polystachya are 
the two most frequent aquatic grasses in the Amazon rivers (Junk, 1970; Colares \& Colares, 1987; Piedade, 1988).

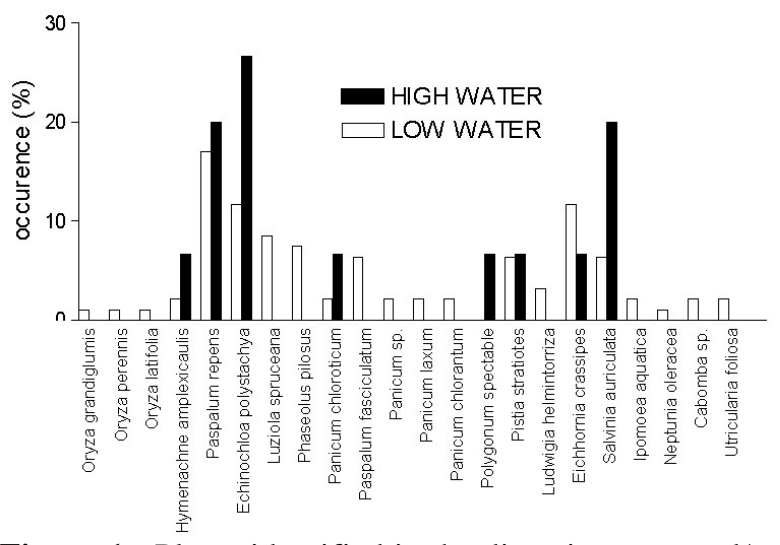

Figure 1 - Plants identified in the digestive tract and/or faeces of the animals in the different times of year. Low water: September to February, and high water: March to August.

Floating Ipomoea aquatica was also identified as the only food item encountered in one sample collected during the low water period, when this species was more abundant in the studied areas (Rodrigues \& Nelson, 1984; Colares \& Colares, 1987). In dugongs, Wake (1975) showed that the percentage of grasses found in the stomach contents and faeces reflected almost perfectly the grass bed composition where they occurred.

The hyacinth Eichornia crassipes was the third most frequent plant in the digestive tracts and faeces analyzed, constituting $11.2 \%$ of the Amazonian manatees diet. Marmol (1976) in Peru and Timm et al. (1986) in Ecuador, also found Amazonian manatee feeding on this species. Some have noted that the West Indian manatees only ate the emergent part of hyacinth, ignoring the roots (Lomolino, 1977). Hartman (1979) noted that $T$. manatus rarely ate this plant but that when it ate, it usually ate the entire plant. We found this species quite frequently in the digestive tract and faeces of the animals with the entire plant being consumed. $T$. inunguis captive at INPA ate the entire plant. But when feeding only on the hyacinth Eichhornia crassipes, intestinal disturbance was evident, since this plant was of difficult digestibility (Colares et al., 1990).

There were some variations in the type of food consumed when comparing both studied areas (Fig. 2), though the most frequent species were the same. In Area 1 the animals fed on 16 species of plants, while in Area 2, they fed on 14 species, of which eight were common for the animals in both of these areas. In the samples from Area 1, the most frequent plant was Paspalum repens, followed by Eichhornia crassipes. In Area 2, the most frequent plants were the grasses Echinochloa polystachya and Paspalum repens, followed by Paspalum fasciculatum. This variation almost reflected the physiographics characteristics of these two areas. The vegetation in the northward of lake Amanã (Area 1) is typical of black waters "igapó" forests. In the southward, the vegetation is "varzea" typical, with aquatic and semi-aquatic macrophytes (Rodrigues \& Nelson 1984). In Area 2 , the vegetation is predominantly herbaceous, composed of aquatic and semi-aquatic macrophytes typical of "varzea" forests (Colares $\&$ Colares 1987; Piedade 1988).

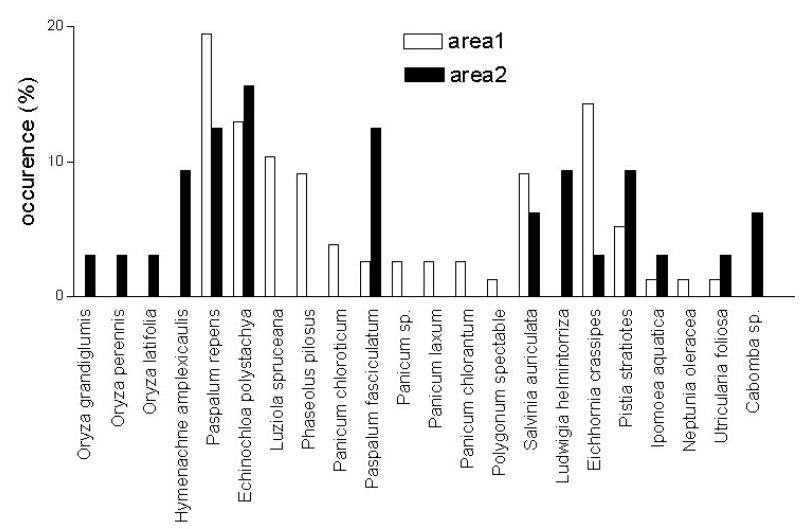

Figure 2 - Plants identified in the digestive tract and/or faeces of the animals from the two large studied areas.

Terrestrial grasses also contribute to the diet of Amazonian manatee, although in small quantities. This may be a reflection grass abundance along the edges of the rivers, lakes and streams. Two species of land grasses, Panicum laxum and Panicum chloroticum, were encountered in the samples from Area 1 during the low water period. Ledder (1986) found a nearly 6\% contribution of land grasses in the diet of West Indian manatees, reflecting their distribution along the rivers and canals where the animals live.

The submerged plants Utricularia foliosa and Cabomba sp. were identified in samples from Area 1 during the low water period. However, the frequency of occurrence was quite low $(1.8 \%$ each), which supported the hypothesis that $T$. inunguis mainly consumed emergent plants. Besides this, during the low water period, plant 
abundance in rivers and lakes of the Amazon basin was very low (Junk, 1970), what constituted an additional evidence of a generalist feeding-habit.

Non-identified algal filaments, animal fragments, grains of sand, and decomposing vegetable matter were also identified in the samples. We believed that these items were attached to vegetation, thus being accidentally ingested with food plants. Similar observations were made in dugongs and West Indian manatees (Lipkin, 1975; Wake, 1975; Ledder, 1986). Hartman (1979) and Best (1981) reported that manatees consumed considerable quantities of organisms which were found in large numbers on the roots and leaves of aquatic macrophytes. The presence of sand grains and decomposing vegetable matter encountered in samples during low water was supported by Best (1981), who indicated that when availability of food decreased during this period, they used decomposing material and mud as a food supplement.

Grass seeds also were identified in the samples. The ingestion of grass seeds by Amazonian manatees was frequent (32\% samples) during low water. However, the majority of these seeds were broken, with degradation starting from the stomach up to the large intestine. In previous observations (Colares, I.G.; pers. obs.), it was noted that when captive Amazonian manatees at INPA were offered branches of aquatic grasses with seeds, the animals ate the seeds first. However, Gonçalves-Colares et al. (1988) have observed that the Amazonian manatee probably were not a good disperser of aquatic grasses.

In conclusion, the present data suggested that rivers and lakes with emergent aquatic vegetation, especially aquatic grasses, were important for the species. However, the generalist feeding-habit allowed to use the most varied resources, as demonstrated during the period of low water, when abundance of emergent aquatic plants were very low.

\section{ACKNOWLEDGEMENTS}

We thank Megumi Yamakoshi for her assistance in the collection of the biological material; Dra. Olga Minura (São Paulo University-Brasil) for her technical support; and all staff of the Aquatic Mammals Laboratory of the National Institute of Amazonian Research (INPA) for their assistance and dedication during the study. The work was supported by the National Research Council of Brazil $(\mathrm{CNPq})$ and INPA.

\section{RESUMO}

Para determinar o hábito alimentar do peixe-boi da Amazonia em alguns rios e lagos da Amazonia Central, nós comparamos as epidermes de plantas encontradas nos conteúdos alimentares e/ou fezes de animais com uma coleção de referência de epidermes de plantas presentes nas áreas de estudo. Foram analisadas 25 amostras de trato digestivo de animais encontrados mortos e 25 amostras de fezes . A familia Gramineae foi encontrada em 96\% das amostras, com maior ocorrência das espécies Paspalum repens e Echinochloa polystachya. A segunda familia mais freqüente foi Pontederiaceae sendo Eichhornia crassipes a espécie predominante. Durante o período de água cheia, os animais apresentaram uma dieta mais seletiva (oito espécies identificadas). Já na água baixa, com menor oferta de alimentos, os animais apresentam uma maior diversidade de espécies em sua dieta (21 espécies de plantas). Diferenças na dieta entre as duas áreas amostrais refletem as características fisiográficas das regiões. $\mathrm{O}$ peixe-boi alimenta-se principalmente de plantas emergentes.

\section{REFERENCES}

Ames, A. L., E. S. Van Vleet and W. M. Sackett. (1996), The use of stable carbon isotope analysis for determining the dietary habits of the Florida manatee, Trichechus manatus latirostris. Marine Mammal Science, 12(4), 555-563.

Anderson, P. K. (1998), Shark Bay dugongs (Dugong dugon) in summer. II. Foragers in a Haloduledominated community. Mammalia, 62(3), 409-425.

Bengtson, J. L. (1981), Ecology of Manatees (Trichechus manatus) in the St. Johns River, Florida. Ph.D. Thesis, University of Minnesota, Minneapolis, USA.

Best, R. C. (1981), Foods and feeding habits of wild and captive Sirenia. Mammal Review, 11(1), 3-29.

Best, R. C. (1984), The aquatic mammals and reptiles of the Amazon. In-The Amazon. Limnology and Landscape Ecology of a mighty tropical river and its basin, ed. H. Sioli, Netherlands, pp. 371-412.

Colares, I. G. and E. P. Colares (1987), Variação anual de vegetais que servem de alimentação para o peixe-boi amazônico (Mammalia-Sirenia), Paper presented at $2^{\text {th }}$ Reunião de Trabalho de Especialistas em Mamíferos Aquáticos da América do Sul, Rio de Janeiro, Brasil, pp. 42-44. 
Colares, F. A. P.; I. G. Colares,; F. C. W. Rosas and E. P. Colares. (1990), Amazonian manatte (Trichechus inunguis): a 15 year long-term study. Paper presented at Proceedings of American Association of Zoo Veterinarians. Annual Meeting. Texas, USA, pp. 43-47.

Domning, D. P. (1978a), Sirenian evolution in the North Pacific Ocean. University of California Publications in Geological Sciences, 118, pp. 176.

Domning, D. P. (1978b), The myology of the Amazonian Manatee, Trichechus inunguis (Natterer) (Mammalia: Sirenia), Suplemento 1 Acta Amazonica, 8(2), pp. 81.

Domning, D. P. (1981), Distribution and status of manatees Trichechus spp. near the mouth of the Amazon river, Brazil. Biological Conservation, 19, 85-97.

Gonçalves-Colares, I., E. P. Colares and A. C. Lima. (1988), Possível dispersão de sementes de gramíneas aquáticas pelo peixe-boi amazônico (Trichechus inunguis), Paper presented at Anais do Simpósio Internacional sobre Ecologia Evolutiva de Herbívoros Tropicais. Universidade Estadual de Campinas, SP, pp. 24.

Gonçalves-Colares, I. and E.P. Colares. (1992), Preferência alimentar do Peixe-boi da Amazônia em cativeiro. Revista "Peixe-boi", 1, 26-32.

Hartman, D. S. (1979), Ecology and behavior of the manatee (Trichechusmanatus) in Florida. The American Society of Mammalogists, Special Publication, 5, pp. 153.

Heinsohn, G. E. and W. R. Birch. (1972), Foods and feeding habits of the Dugong, Dugong dugong (Erxleben) in northern Queensland, Australia. Mammalia, 36, 414-422.

Husar, S. L. (1977), Trichechus inunguis. Mammalian Species, 72, 1-4.

Junk, W. J. (1970), Investigations on the ecology and production biology of the "floating meadows" (Paspalum-Echinochloetum) on the Middle Amazon. I. The floating vegetation and its ecology. Amazoniana, 2(4), 449-495.

Ledder, D. A. (1986), Food habits of the West Indian Manatee, Trichechus manatus latirostris, in south Florida. M.Sc.Thesis, University of Miami, Florida, USA.

Lipkin, Y. (1975), Food of the Red Sea Dugong (Mammalia: Sirenia) from Sinai. Israel Journal of Zoology, 24, 81-98.

Lomolino, M. V. (1977), The ecological role of the Florida Manatee (Trichechus manatus latirostris) in waterhyacinth dominated ecosystem. M.Sc. Thesis, University of Florida, USA.

Marmol, B. A. E. (1976), Informe preliminar sobre las plantas que sirven de alimento al manati, de la Amazonia (Trichechusinunguis), Paper presented at Primer Congresso Nacional de Botánica, Lima, Peru, pp. 31-32.
Marsh, H.; P. W. Channells; G. E. Heinsoh and J. Morrissey. (1982), Analysis of stomach contents of Dugongs from Queensland. Australian Wildlife Research, 9, 55-67.

Montgomery, G. G.; R. C. Best and M. Yamakoshi. (1981), A radio-tracking study of the Amazonian manatee Trichechus inunguis (Mammalia: Sirenia), Biotropica, 13(2), 81-85.

Packard, J. M. (1981), Abundance, distribution and feeding habits of Manatees (Trichechus manatus) wintering between St. Lucie and Palm Beach Inlets, Florida. Final Report. U.S. Fish and Wildlife Service, pp. 142.

Piedade, M. T. F. (1988), Biomassa, produtividade e atividade fotossintética de Echinochloa polystachya (H.B.K.) Hitchcock (Gramineae = Poaceae), capim semi-aquático da várzea amazônica. Ph.D. Thesis, INPA/FUA, Manaus, Amazonas, Brasil.

Reynolds, J. E. III. (1977), Aspects of the social behavior and ecology of a semi-isolated colony of Florida manatees, Trichechusmanatus. M.Sc. Thesis, University of Miami, Florida, USA.

Rodrigues, W. A. and B. W. Nelson. (1984), Observações sobre a vegetação e geomorfologia feitas em vôo de reconhecimento sobre o Lago Amanã, estado do Amazonas. Projeto Flora. INPA, Manaus, Brasil, pp. 21.

Rosas, F. C. W. (1994), Biology, conservation and status of the amazonian manatee Trichechus inunguis. Mammal Review, 24(2), 49-59.

Rosas, F. C. W.; E. P. Colares; I. G. Colares and V. M. F. Silva. (1991), Mamíferos Aquáticos da Amazônia Brasileira. In-Bases científicas para o estabelecimento de estratégias de preservação e desenvolvimento da Amazônia: fatos e perspectivas, ed. Val, A. L., $R$. Figliuolo and E. Feldberg, 1, 405- 411.

Sioli, H. (1968), Hydrochemistry and geology in the Brazilian Amazon region. Amazoniana, 1, 267-277.

Storr, G. M. (1961), Microscopic analysis of faeces, a technique for ascertaining the diet of herbivorous mammals. Australian Journal of Biology and Science, 14(1), 157-166.

Timm, R. M.; V. L. Albuja and B. L. Clauson. (1986), Ecology, distribution, harvest, and conservation of the Amazonian Manatee Trichechus inunguis in Ecuador. Biotropica, 18(2), 150-156.

Wake, J. A. (1975), A study of the habitat requirements and feeding biology of the dugong, Dugong dugon (Muller), Bachelor of Science Thesis, James Cook University, North Queensland, Australian.

Received: May 30, 2000; Revised: October 20, 2000; Accepted: March 19, 2001. 